\title{
Cuban Meningococcal Vaccine VA-MENGOC-BC: 30 Years of Use and Future Potential
}

\section{Gustavo Sierra-González MD PhD}

\begin{abstract}
Every year, meningococcal infection by Neisseria meningitidis causes over 500,000 cases and 85,000 deaths in the world, with $20 \%$ of survivors suffering sequelae. In Cuba its incidence in 1980 reached 5.9 cases per 100,000 population; about $80 \%$ of cases were serogroup $\mathrm{B}$, prompting health authorities to declare meningococcal disease the country's main public health problem.

Several provinces reported over 120 cases per 100,000 children aged $<1$ year, overwhelmingly serogroup B. At that time, no vaccines existed with proven efficacy against $N$. meningitidis serogroup $B$, nor was there a vaccine candidate that could be successful in the short term. By 1989, researchers in Havana had developed a Cuban meningococcal $B$ and $C$ vaccine, VA-MENGOC-BC, the world's first against serogroup $B$ meningococcal disease. Its efficacy of $83 \%$ was demonstrated in a prospective, randomized, double-blind, placebo-controlled field study. Vaccine production used vesicle or proteoliposome technology for the first time. The same year, the World Intellectual Property Organization awarded its gold medal to the main authors of the VA-MENGOC-BC patent.
\end{abstract}

\section{INTRODUCTION}

Meningococcal disease, caused by infection with Neisseria meningitidis, has been greatly feared since the 19th century[1] and is still a global public health problem. Its main variants are meningitis and septicemia, both severe conditions and leading causes of invasive bacterial infection.[2]

Worldwide, annual incidence ranges from 1 to 27.5 per 100,000 population. During epidemics in the "meningitis belt" (SubSaharan African countries from The Gambia to Sudan), up to $1 \%$ of the population might become ill.[3,4] Overall case fatality is $5.3 \%-26.2 \%$, with an average of $14.4 \%$. During an epidemic in Africa, case fatality can exceed 30\%.[5] Despite underreporting in many areas, it is estimated that there are over 500,000 cases and over 85,000 deaths every year. Twenty percent of survivors have sequelae, with risk in Africa triple that of the USA or Europe.[6]

There are millions of asymptomatic nasopharyngeal carriers of $N$. meningitidis in the world who can transmit the disease to others. Reported frequency is greatest in young adults (10\%-35\%).[7]

IMPORTANCE This article reviews development, characteristics, trials and use of the Cuban vaccine VA-MENGOC-BC, the world's first effective vaccine against serogroup B meningococcal infection, 30 years after its efficacy was demonstrated. The paper also describes its impact on population health in Cuba and other countries, especially in children and young people, as well as the contributions of its production technology to scientific and technological advances in the biotechnology industry.
The vaccine was used in a mass vaccination campaign and later included in Cuba's National Immunization Program, with a cumulative impact on incidence of serogroup B meningococcal disease greater than 95\% (93\%-98\%). Mass, systematic vaccination shifted the spectrum of meningococcal strains in healthy asymptomatic carriers and strains circulating among population groups toward nonvirulent phenotypes. The disease ceased to be a public health problem in the country. VAMENGOC-BC is the most widely applied vaccine against serogroup $B$ meningococcal disease in the world. Over 60 million doses have been administered in Latin America. In several countries where it has been applied, in which strains other than the vaccine-targeted strains circulate, VA-MENGOC-BC has demonstrated effectiveness against all $(55 \%-98 \%$ in children aged $\leq 4$ years and $73 \%-100 \%$ in children aged $>4$ years). The vaccine and its proteoliposome technology have had an impact and continue to have potential, not only for meningococcal disease, but also for development of other vaccines and adjuvants.

KEYWORDS Neisseria meningitidis, meningococcal disease, meningococcal vaccine, biotechnology, pharmaceutical industry, bacterial meningitis, meningococcal meningitis, immunization, vaccination, Cuba
In the 1960s, meningococcal disease was considered a public health problem only in tropical countries, but in the 1970s, this view changed with the appearance of outbreaks in Europe and North America. Since World War II, the main epidemics have been in Sub-Saharan African countries, including the meningitis belt, where $60 \%$ to $65 \%$ of all meningitis cases are meningococcal meningitis. However, meningococcal disease now occurs on every continent. Meningococcal disease caused by serogroup B meningococci occurs mainly in the countries of North America, central and southern Europe, southern and northeastern Africa, the Middle East, Russia, China, Japan, Australia and New Zealand.[3] During the early 1980's, when Cuba was just beginning vaccine development for later preclinical and clinical assessment, production and use, the country was a hot spot on the map of worldwide meningococcal disease burden, reaching an all-ages incidence of 14.4 cases per 100,000 population by 1984 . After mass vaccination was instituted, beginning in 1989, meningococcal disease ceased to be a public health problem and Cuba no longer appears among the hot spots still found in other regions.

This article assesses the importance and current relevance of meningococcal disease in the world, its status in Cuba and results of the Cuban meningococcal BC vaccine, VA-MENGOC-BC, since its development. It analyzes, among other aspects, the impact of the vaccine's application, its current usefulness, relevance of its pioneering technology and its contribution to Cuban and global scientific development.

\section{MENINGOCOCCAL DISEASE IN CUBA,} VACCINE DEVELOPMENT AND USE

Meningococcal disease, characteristics and burden in Cuba: confronting and solving the problem From 1916 to the mid- 
1970s, Cuba experienced only sporadic cases of meningococcal disease. In 1976, outbreaks began to occur that ballooned into epidemics. In 1978, incidence was 1.5 per 100,000 population and by 1979 it had reached 5.6 per 100,000 population. Over $50 \%$ of cases were caused by serogroup C and close to $35 \%$ by serogroup B. Most affected were children aged 10-14 years, followed by those aged $<1$ year.[8]

In 1979, Cuba undertook a vaccination campaign to control the disease; 3,245,046 people aged 3 months-19 years were vaccinated with meningococcal $A C$ vaccine (Merieux, FR), for over $80 \%$ coverage. Incidence due to serogroup C decreased, but meningococcal disease continued to increase, and in 1980 reached 5.9 per 100,000 population; case fatality was $10 \%-$ $25 \%,[8,9]$ and about $80 \%$ of cases were due to serogroup $B$. That year, meningococcal disease was declared the country's main public health problem. By 1984, overall incidence had risen to 14.4 per 100,000 population. Several provinces reported $>120$ cases per 100,000 children aged $<1$ year.[8]

At that time, no vaccine existed in the world with proven efficacy against serogroup B $N$. meningitidis, nor was there a vaccine candidate that could be successful in the short term. The highest development achieved by the most advanced groups was a serotype-specific antigen vaccine; its characteristics are summarized in Box 1 and compared with the Cuban vaccine.[9-12]

From 1980 to 1986, Cuban scientists at the National Center for Meningococcal Vaccine Development in Havana (precursor to the Finlay Vaccine Institute, founded in 1991), developed a vaccine candidate based on outer membrane vesicles (OMVs or proteoliposomes). Its clinical efficacy was field tested from 1987 to 1989. Developing this vaccine candidate involved creating a scalable and integrated production system with complex know-how for initial culture, fermentation, extraction, purification, formulation, adjuvantation, bottling and packaging. Stable OMVs were obtained, with a lipopolysaccharide composition apt for administration in humans without toxicity while conserving contribution to immunogenicity (Box 1).

With technological innovations in the development of VAMENGOC-BC, patents were registered[13,14] that obtained licenses in Cuba[18] and, through the Patent Cooperation Treaty, in Australia and countries of the Americas, Europe, Asia and Africa. In 1989, the World Intellectual Property Organization awarded its gold medal to the main authors of the VA-MENGOC-BC patent. Their most important scientific achievements were obtaining immunogenic and stable OMVs or proteoliposomes from serogroup B meningococcus; the development process; and the product, whose composition, formulation and efficacy differed from existing vaccine candidates. Proteoliposomes or OMVs constitute the fundamental structure that ensures vaccine's immunogenicity and protective capacity. OMV characteristics are shown in Figure 1, and Box 2 describes the vaccine's formulation, as well as functions of the mixture and of several of the molecules formed.

Studies of the vaccine before licensing and mass administration From 1987 to 1989, a prospective, randomized, double-blind, placebo-controlled efficacy study was carried out in 7 provinces, involving 106,251 youngsters aged 10-16 years.
Box 1: Meningococcal B Vaccines Characteristics Serotype-specific antigen vaccines (1970-1978)

Vaccines based on purified serotype-specific antigens, with adjuvants and without outer membrane vescicles (OMVs). Experimental formulations included capsular polysaccharides from other groups for better solubility. Lipopolysaccharide was mainly free or formed part of blebs or membrane fragments and had to be eliminated to the extent possible, due to its toxicity.

These were laboratory-scale efforts, lacking established technologies and good manufacturing practices. There was no demonstrated correlate of protection in controlled efficacy tests in humans. The few vaccines that were subject to trials in humans were discontinued. They required use of aluminum hydroxide as an adjuvant and to reduce toxicity.[9-12]

\section{Cuban Vaccine VA-MENGOC-BC (1982-1989)}

This is an OMV or proteoliposome vaccine. Its serological and overall efficacy is related to OMV presence, stability and consistency. The vesicular structure gives adjuvant and immunostimulating properties. OMVs provide the polysaccharide and other low immunogenic antigens with some degree of thymus dependence and enhance immune response to them.

Lipopolysaccharide is integrated into OMVs and may or may not adsorb to $\mathrm{Al}(\mathrm{OH})_{3}$ gel. VA-MENGOC-BC's adjuvant capacity does not depend on $\mathrm{Al}(\mathrm{OH})_{3}$, but instead on OMVs, which also contain the proteins necessary for protection against a broad spectrum of heterologous strains.[13-16] The main role of $\mathrm{Al}(\mathrm{OH})_{3}$ in VA-MENGOC-BC is to achieve pharmaceutical stability, which is supported by results with new formulations without aluminum hydroxide in preclinical development.[17]

Researchers from the Finlay Vaccine Institute, Cuba's Ministry of Public Health, Cuba's Center for State Control of Medicines and Medical Devices, PAHO/WHO, and the US CDC participated in discussion of the final trial protocol and its evaluation.

The field study lasted 16 months, during which 25 cases of meningococcal disease occurred. Once concluded, the blinding code was broken, revealing whether cases were in the placebo or vaccinated group: there were 4 cases among the 52,966 who received the vaccine, and 21 among the 53,285 who received the placebo. Estimated efficacy was 83\% ( $p=0.0019)$.[16] VA-MENGOC-BC thus became the world's first vaccine against serogroup $B$ meningococcus found effective in a prospective, double-blind, placebo-controlled field trial.

In 1989, preclinical studies and phase I, II and III clinical trials required by national and international regulatory authorities were completed, and Cuba's Center for State Control of Medicines and Medical Devices-the Cuban regulatory agency-licensed VAMENGOC-BC for marketing.[18] 
Figure 1: Characteristics of VA-MENGOC-BC

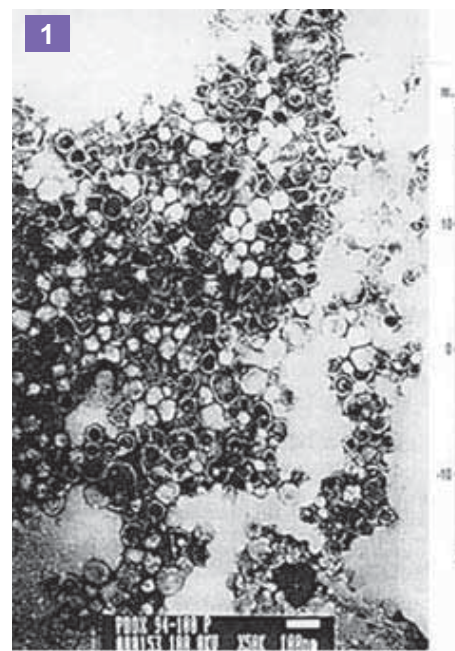

$2 a$

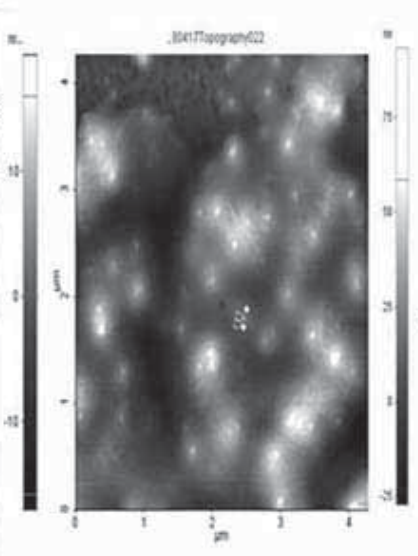

$2 b$

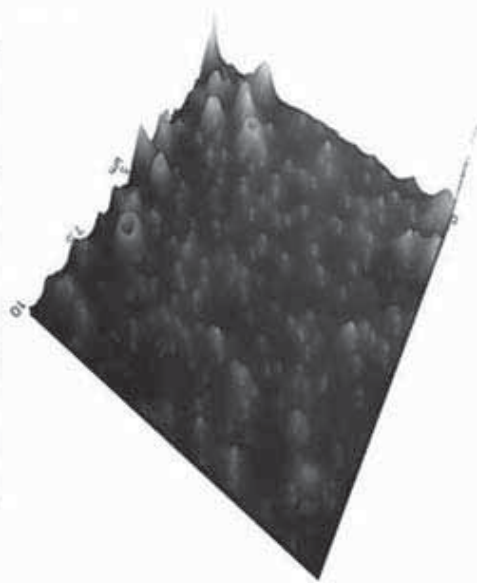

Outer membrane vesicles of strain CU-B385/3 of serogroup B Neisseria meningitidis, basic core of VA-MENGOC-BC Electron micrographs of proteoliposomes or outer membrane vesicles (OMVs). Vesicles 50-80 nm in diameter can be seen. Well-defined and chemically and physically stable OMVs or proteoliposomes are the heart of VA-MENGOC-BC and ensure its immunogenicity and protective capacity.

1) transmission electron microscopy

2a) two-dimensional atomic force microscopy

2b) three-dimensional atomic force microscopy. Digital Nanoscope III AFM (Santa Barbara, CA) coupled to scanner (J-Scanner) of $125 \mu \mathrm{m}$, Software used UTHSCSA Image Trial (USA).

Vaccination results from 1989 to 2019 With the vaccine registered, Phase IV (postmarketing surveillance) began. In 1989 and 1990, a national campaign was carried out, in which more than 3 million people aged 3 months-24 years were vaccinated, for over 95\% coverage. High-risk groups were also included, mainly workers and students living in dormitories, prisoners, health personnel, etc., regardless of age, prioritized by province according to disease incidence. $[8,16]$

In 1991, VA-MENGOC-BC was added to the National Immunization Program, where it has remained without interruption or essential changes, using a 2-dose schedule, the first at age 3 months and the second at age 5 months. This universal and systematic immunization in infancy maintained coverage for those who were born after the mass vaccination campaign.

Annual incidence of meningococcal disease in Cuba before vaccination averaged 14.4 per 100,000 population. Following vaccination, the rate decreased to $\leq 1$ per 100,000 population in 1993 and has remained below 0.1 per 100,000 population since 2008. In children aged $\leq 6$ years, average annual incidence before vaccination was $38-120$ per 100,000 , and this dropped to $0.01-$ 1.8 per 100,000 population in the following two decades. The reduction was an estimated 95\% (93\%-98\%) and meningococcal disease has been eliminated as a public health problem in Cuba. $[8,16,21-23]$

Impact of mass vaccination on strain patterns in carriers and patients In the prevaccination epidemic stage, a cumulatively total of $96.8 \%$ of strains isolated from patients were from serogroup $B$, $1.4 \%$ from $C$, and $1.8 \%$ were not groupable. In carriers, $67.3 \%$ were from serogroup $B$, and $32.7 \%$ were not groupable. The vaccination campaign changed strain distribution: $100 \%$ of patients were now from serogroup $B$. In healthy carriers, strain distribution shifted to $26.7 \%$ from serogroup B and $70.8 \%$ from nongroupable strains, while serogroup W-135 appeared in $2.5 \%$ of cases.[24] Selective pressure by the vaccine, which was over 95\% effective against group B (demonstrated by decreased incidence and reduced B capsule expression in healthy carriers from $67.3 \%$ to $26.7 \%$ ) had not been previously described for any meningococcal $B$ vaccine.

Changes in serotypes and subtypes in postvaccination patients and carriers can be interpreted as an expression of broad-spectrum vaccine-induced immune response, as epidemic serotypes and subtypes were eliminated or decreased and nontypable and nonsubtypable serotypes and subtypes increased in patients and carriers. Serotypes and subtypes different from the vaccine strain did not increase in patients or carriers. The vaccine was effective against homologous strains and also against heterologous strains.[24] Frequency and diversity of hypervirulent clonal complexes (ST-32 and ST-41/44) in patients and carriers decreased after vaccination and were replaced by the ST-53 complex, which represents a positive change. [25] After 2008, four serotype B:17 strains, never before reported in Cuba, appeared. Before this, between October 2004 and March 2005 , strain $\mathrm{B}: 17: \mathrm{P} 1.19$, belonging to a new circulating clone (ST269), was reported in Canada.[26]

These changes are favorable because two of the most important hypervirulent clones in the cause and expansion of Cuba's

Box 2: Additional characteristics of VA-MENGOC-BC VA-MENGOC-BC is a bivalent vaccine of serogroups $B$ and $\mathrm{C}$ meningococcal antigens, which forms a stable mixture adsorbed to $\mathrm{Al}(\mathrm{OH})_{3}$ gel. Each dose contains $50 \mu \mathrm{g}$ of membrane proteins, with $2 \mu \mathrm{g}$ of serogroup $\mathrm{B}$ lipopolysaccharide, integrated in the OMVs, and $50 \mu \mathrm{g}$ of serogroup C polysaccharide, as well as $2 \mathrm{mg}$ of $\mathrm{Al}(\mathrm{OH})_{3}$ gel, a formulation buffered with phosphates and sodium chloride at physiological $\mathrm{pH}$; this mixture allows stable adsorption of the protein-polysaccharide-lipopolysaccharide complex, suitable for immune system delivery.

Proteomics has demonstrated the basis of its broad protective spectrum. Integration into the vesicles and adsorption to the gel detoxifies the lipopolysaccharide and assures conservation of its adjuvant properties, necessary in the formulation. OMVs constitute the fundamental adjuvant capable of provoking a potent Th-1 type immune response pattern.[18-20] 
epidemic and others in the world were eliminated, in addition to the change in carrier phenotypes to nonvirulent variants and the transformation of epidemic strains in patients. However, it is necessary to carefully assess the possible importance of the appearance, although very limited, of clone ST-53, and whether the B:17 strains found are of the ST-269 type, as in Canada, as well as the levels of protection conferred by the Cuban vaccine against these strains.

Importance of immunization schedule and coverage in VA-MENGOC-BC's effectiveness Despite the 95\% impact and protection achieved by the National Immunization Program's high coverage, as demonstrated over the past 30 years, there are indications that duration of postimmunization protection has decreased with the two-dose VA-MENGOC$\mathrm{BC}$ schedule used in Cuba, particularly in children up to age one year. Although protection decreases over time, it was demonstrated that the vaccine was effective with the twodose schedule and that it provides better protection against meningococcemia, which is more severe and lethal, than against the meningeal form.[27]

Decreased protection time with the program's schedule is due to the fact that bacterial vaccines' lower immunogenicity requires primary schedules of more than two doses, with boosters in the initial schedule[27] and even booster doses after a certain period or when the immune system is stressed. The superiority of a threedose schedule for VA-MENGOC-BC has been demonstrated in studies conducted in Cuba and other countries.[16,28-30]

In conclusion, the vaccine could offer higher protection in infants and against the clinical meningeal form if an initial immunization schedule with three or more doses, along with a booster (which improves maturation of the immune response) were instituted; this should therefore be considered. However, even if the number of doses is increased, it is advisable to maintain the high coverage that has demonstrated effectiveness and sustained impact, and that will contribute to elimination of the disease.

\section{ADMINISTRATION OF MENINGOCOCCAL HYPERIMMUNE GAMMAGLOBULIN (HGG) \\ IN SEVERELY ILL CHILDREN}

Participants in the vaccine registration clinical trials donated blood to obtain plasma, where vaccine-induced antibodies were in high concentrations. Globulins[31,32] were purified, their composition and concentrations characterized, and basic preclinical and toxicological studies performed.[32,33] Several lots of meningococcal HGG were produced and released by the national regulatory authority for experimental use in sick children whose lives were at risk.

Meningococcal HGG was used to conduct a clinical trial that included 123 children diagnosed with meningococcal disease in 21 intensive care units in 9 provinces.[31,32] For ethical reasons, results from the historical series were used as a comparison and meningococcal HGG was administered to all children in the trial.

Cases were stratified according to number of poor prognostic factors (PPFs). PPFs were established based on clinical assessment and disease course of patients in the epidemic's historical series. To evaluate effectiveness of meningococcal HGG administration, survival results in the clinical trial were compared with those with the same number of PPFs reported in the historical series.

Treatment followed established standards for patients with given numbers of PPFs, along with meningococcal HGG. In children with up to 2 PPFs, conventional treatment plus meningococcal HGG achieved $100 \%$ survival. With 3 or 4 PPFs, the respective survival percentages with conventional treatment were $86 \%$ and $78.5 \%$, while in both cases survival was $100 \%$ with meningococcal HGG. Patients with 5 PPFs (serious, in clinical status terminology) had $53 \%$ survival with conventional treatment and $88.9 \%$ survival when meningococcal HGG was added. Children with 6 PPFs (classified as critical) had $21.4 \%$ survival with conventional treatment and $62.5 \%$ when meningococcal HGG was added. With 7 or 8 PPFs, administration of meningococcal HGG did not improve survival.

Certain combinations of PPFs had high case fatality and very low survival $(20 \%)$ with conventional treatment, such as cases with a platelet count $<150,000,+$ shock, + acidosis $(\mathrm{pH}<7.3)$. When meningococcal HGG was administered, survival increased to $62.5 \%$. These results provided new evidence supporting the protective capacity of vaccine-induced antibodies.[31,32]

\section{POTENTIAL OF VA-MENGOC-BC}

\section{IN PREVENTION OF GONORRHEA}

Two bacterial species of the genus Neisseria, $N$. meningitidis and $N$. gonorrhoeae, are antigenically related commensals and pathogens exclusive to humans. The first causes meningococcal disease and the second causes gonorrhea, a sexually transmitted infection. Gonococci have become resistant superbacteria and are a growing problem, with no vaccine to prevent them.[34,35]

Laboratory studies conducted in Havana at the Finlay Vaccine Institute and the Pedro Kourí Tropical Medicine Institute (IPK) demonstrated cross reactions among Neisseria species antibodies in serum and secretions when VA-MENGOC-BC was administered to mice. Elements of a cellular response induced by VA-MENGOC-BC against gonococci were also identified, which could have contributed to the reduction of gonorrhea incidence after mass campaigns with this vaccine (at the time, there were also public health campaigns specifically directed at reducing sexually transmitted infections).[36]

In a case-control study conducted in New Zealand, those who received the meningococcal vaccine had a significantly lower risk of gonorrhea than those who were not vaccinated (OR 0.69, $p<0.001$ ).[37] Another New Zealand study with the same vaccine reported an overall effectiveness of $31 \%$ and a $47 \%$ effectiveness against hospitalization attributable to gonorrhea in one cohort.[38]

\section{ADVANCES IN THE FIELD OF ADJUVANTS FOR HUMAN}

\section{VACCINES: TECHNOLOGICAL PACKAGE AND PATENTS}

The most widely used technological platform in Cuba for human vaccine adjuvants is based on proteoliposome technology to obtain OMVs from N. meningitidis strain CU-B385/3. This technology, which was used to manufacture more than 70 million doses of meningococcal vaccine, produced a family of patents, new vaccines and opportunities for biomedical and biotechnology development. 
Figure 2: Platform developed using vesicular or proteoliposome technology
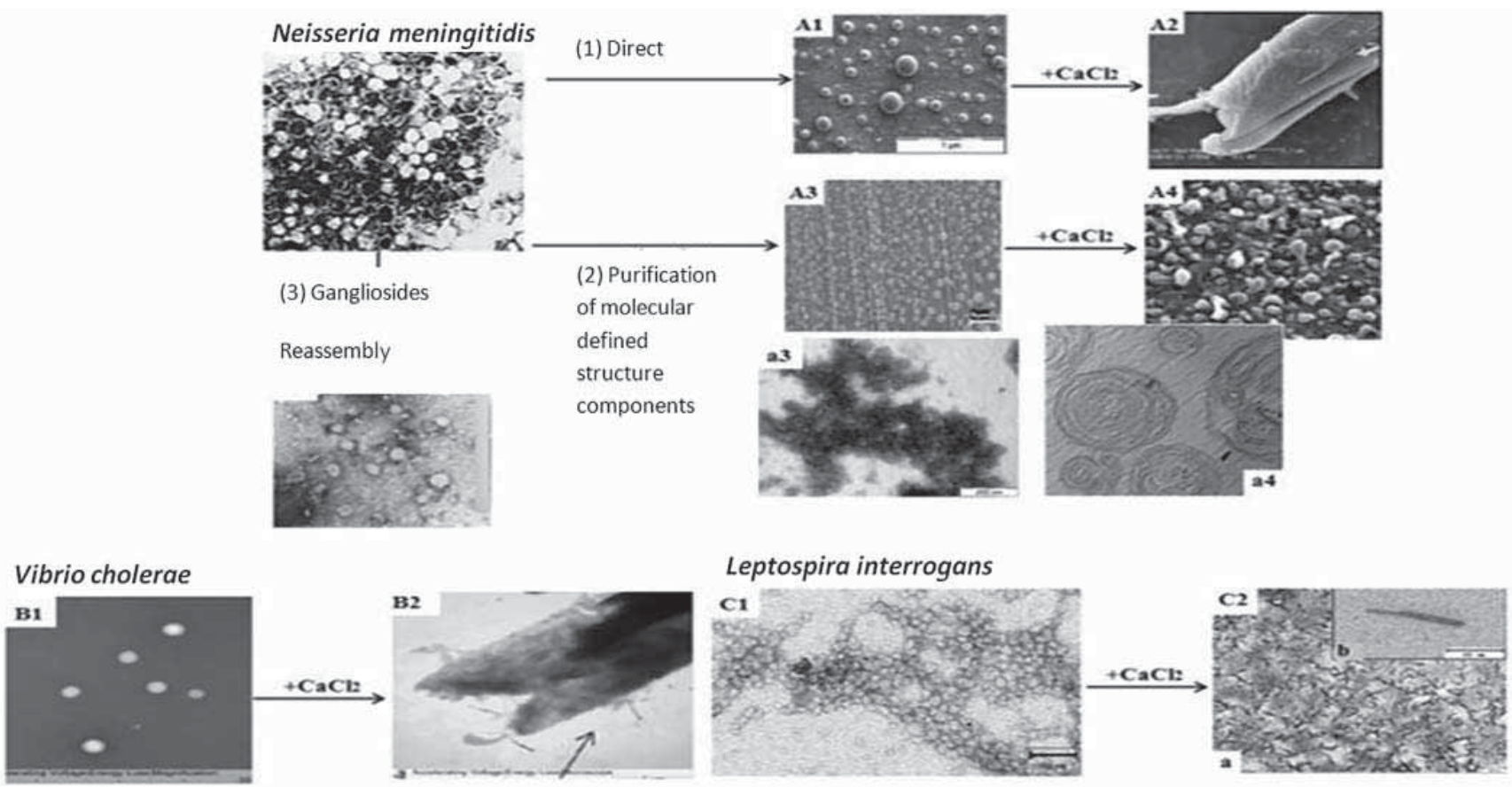

Electron micrographs of the adjuvant formulation platform with proteoliposome and cochlear structure, developed using technology from the Finlay Vaccine Institute, to obtain N. meningitidis $B$ outer membrane vesicles (OMVs)

1) $A, A 1, A 2$ new OMVs and cochleates obtained directly from originals

2) $A, A 3, A 4, a 3, a 4$ a new generation of nano-OMVs and nanocochleates

3) very small size proteoliposomes with gangliosides, obtained directly from OMVs

The four photos in the lower block represent application of vesicular technology to cholera $(B 1, B 2)$ and leptospirosis $(C 1, C 2)$ vaccines.[39]

Table 1: Technology package. Know-how for new adjuvants and vaccines based on vesicular VA-MENGOC-BC technology

\begin{tabular}{|c|c|c|c|c|}
\hline Document & Patent & PP & Biotechnology product(s) & Reference \\
\hline CU 21888A1 & $x$ & - & Vaccine against $N$. meningitidis B & [13] \\
\hline EP 0301992B1 & $\mathrm{x}$ & - & $\begin{array}{l}\text { Vaccine, gammaglobulin and transfer } \\
\text { factor, } N \text {. meningitidis }\end{array}$ & [14] \\
\hline WO 2004/047805A1 & $\mathrm{x}$ & - & $\begin{array}{l}\text { Cochleate-based vaccines and } \\
\text { adjuvants }\end{array}$ & [40] \\
\hline WO 2003/094964A1 & $x$ & - & Allergy vaccines and treatments & [41] \\
\hline WO 2010/057447A1 & $\mathrm{x}$ & - & Vaccines and types of administration & [42] \\
\hline WO 2011/137876A2 & $x$ & - & Tolerogenic, malaria vaccines & [43] \\
\hline WO 2002/45746A2 & $x$ & - & $\begin{array}{l}\text { Poorly immunogenic antigen adjuvant } \\
\text { (cancer) }\end{array}$ & [44] \\
\hline Vaccine (1999) & - & $x$ & $\begin{array}{l}\text { Poorly immunogenic antigen adjuvant } \\
\text { (cancer) }\end{array}$ & [45] \\
\hline VacciMonitor (2012) & - & $\mathrm{X}$ & $\begin{array}{l}\text { Leptospira nanocochleates and } \\
\text { proteoliposomes }\end{array}$ & [46] \\
\hline BMC Immunol (2013) & - & $\mathrm{x}$ & $\begin{array}{l}\text { New N. meningitidis B vaccine, without } \\
\mathrm{Al}(\mathrm{OH})_{3}\end{array}$ & [17] \\
\hline J Sci Tot Env (2019) & - & $\mathrm{X}$ & $\begin{array}{l}\text { Meningococcal nanocochleates, nano- } \\
\text { proteoliposomes }\end{array}$ & [19] \\
\hline Rev Chim (2019) & - & $\mathrm{x}$ & $\begin{array}{l}\text { Immunotoxicological evaluation vaccine } \\
\text { without aluminum hydroxide }\end{array}$ & [20] \\
\hline Methods (2009) & - & $\mathrm{x}$ & $\begin{array}{l}\text { Proteoliposome \& cochleates from } \\
\text { Vibrio cholerae } 01\end{array}$ & [47] \\
\hline BMV Immunol (2013) & - & $x$ & Bordetella pertussis acellular vaccine & [48] \\
\hline
\end{tabular}

PP: primary publication
A new therapeutic allergy vaccine currently in clinical trials uses proteoliposome technology as an adjuvant. Therapeutic vaccines under development against several types of cancer also use variants of proteoliposome vesicular technology as adjuvants. The new generations of experimental meningococcal, leptospirosis, cholera and pertussis vaccines also use OMV technology in their production.[39] Figure 2 and Table 1 summarize these aspects.

\section{OTHER SCIENTIFIC AND}

\section{TECHNOLOGICAL ADVANCES MADE}

\section{IN THE MENINGOCOCCAL VACCINE}

\section{MACROPROJECT}

Scientific and technological package, selected patents and publications Genetic engineering technologies were used to clone and obtain important proteins for new generations of serogroup $B$ meningococcal vaccines: PorA, PorB, OpcA, NadA, Tbp, NspA, NlpB, IpdA, and others, and variants of some of these.[49,50]

Serogroup B polysaccharide peptide mimotopes were obtained and characterized by phage display technology, which opened new vaccine potential based on B polysaccharide and prevented possible development of autoimmunity.[51] 
Table 2: Scientific technological package. Meningococcal vaccine macroproject's selected patents and primary publications

\begin{tabular}{|c|c|c|c|c|}
\hline Document (year) & Patent & PP & Biotechnology Products & Reference \\
\hline EP 0474313A2 & $\mathrm{x}$ & - & $\begin{array}{l}\text { P64k protein-r, carrier (cancer, } \\
\text { infectious diseases) }\end{array}$ & [55] \\
\hline WO 2009/003425Al & $x$ & - & $\begin{array}{l}\text { CIMAvax- EGF (cancer therapeu- } \\
\text { tic vaccine) }\end{array}$ & [56] \\
\hline CU 2006/0020 & $x$ & - & $\begin{array}{l}\text { Mimetic peptides of } N \text {. meningiti- } \\
\text { dis polysaccharide B }\end{array}$ & [57] \\
\hline USP 5747653A & $x$ & - & $\begin{array}{l}\text { Hyperimmune gammaglobulin } \\
\text { and its method }\end{array}$ & [58] \\
\hline Int J Med Micr (2011) & - & $\mathrm{x}$ & $\begin{array}{l}\text { Mimetic peptides of } N \text {. meningiti- } \\
\text { dis polysaccharide } B\end{array}$ & [51] \\
\hline Exp Rev Vaccines (2015) & - & $x$ & $\begin{array}{l}\text { CIMAvax-EGF-P64K (lung cancer } \\
\text { therapeutic vaccine) }\end{array}$ & [59] \\
\hline BBRC 308 (2003) & - & $x$ & Dengue virus-P64k protein-r & [60] \\
\hline Doctoral thesis (2006) & - & $x$ & $\begin{array}{l}\text { Human meningococcal immuno- } \\
\text { globulin }\end{array}$ & [32] \\
\hline Proteomics (2006) & - & $x$ & $\begin{array}{l}\text { Characterization of vesicles of } \\
\text { VA-MENGOC-BC }\end{array}$ & [52] \\
\hline Hum Vaccine (2009) & - & $x$ & $\begin{array}{l}\text { Characterization of vesicles of } \\
\text { VA-MENGOC-BC }\end{array}$ & [53] \\
\hline Microb Pathogen (1997) & - & $x$ & $\begin{array}{l}\text { Acquisition of } N \text {. meningitidis iron- } \\
\text { regulated proteins }\end{array}$ & [49] \\
\hline Biotecnología Aplicada (2008) & - & $x$ & $\begin{array}{l}\text { Genetic and immunological } \\
\text { properties NIpB antigen }\end{array}$ & [50] \\
\hline
\end{tabular}

PP: primary publication

Table 3: Efficacy/effectiveness of VA-MENGOC-BC in populations and age groups of various countries

\begin{tabular}{|c|c|c|c|c|c|}
\hline \multirow[t]{2}{*}{ Place } & \multirow[t]{2}{*}{ Date } & \multirow[t]{2}{*}{ Age group } & \multicolumn{2}{|c|}{$\begin{array}{c}\text { Efficacy } \\
\text { leffectiveness by } \\
\text { age group }(\%)\end{array}$} & \multirow[t]{2}{*}{ Reference } \\
\hline & & & $\leq 4$ years & $>4$ years & \\
\hline $\begin{array}{l}\text { Cuba } \\
\text { (7 provinces) }\end{array}$ & $1987-1989$ & $10-16$ years & - & $83^{a}$ & [16] \\
\hline $\begin{array}{l}\text { Cuba } \\
\text { (12 provinces) }\end{array}$ & $1988-1990$ & 3 months -4 years & 93 & - & {$[61,62]$} \\
\hline $\begin{array}{l}\text { Cuba } \\
\text { (14 provinces) }\end{array}$ & $1989-1994$ & 3 months -4 years & 81 & - & [62] \\
\hline Cuba & $1997-2008$ & $<1$ year & 84 & - & [27] \\
\hline $\begin{array}{l}\text { Brazil } \\
\text { (Sta. Catarina) }\end{array}$ & 1990-1992 & 3 months -7 years & 66 & 88 & [63] \\
\hline $\begin{array}{l}\text { Brazil } \\
\text { (Rio de Janeiro) }\end{array}$ & 1990-1992 & 6 months -9 years & 64 & 82 & [64] \\
\hline $\begin{array}{l}\text { Brazil } \\
\text { (Sao Paulo) }\end{array}$ & $1990-1991$ & 3 months -6 years & $55^{b}$ & 73 & {$[65,66]$} \\
\hline Colombia (Antioquia) & 1991-1994 & 3 months -4 years & 98 & - & [67] \\
\hline Uruguay (Canelones) & 2002-2003 & $4-19$ years & - & 100 & [68] \\
\hline Uruguay (Montevideo) & 2002-2003 & $4-19$ years & - & 88 & [68] \\
\hline
\end{tabular}

aefficacy with placebo and vaccine in prospective, randomized double-blind design beffectiveness in the prospective arm of study cal diagnosis of VA-MENGOC-BC-induced immune response in field studies, to evaluate population immunity, and to quantify concentrations of meningocococcal immunoglobulin $\mathrm{G}$ from hyperimmune plasmas used in production of meningococcal HGG.[32]

The genetically engineered recombinant protein of $N$. meningitidis P64K was used as a carrier for vaccines, and its N-terminal is part of genetic constructs that enable high levels of fusion-protein expression. It is included in the structure of dengue vaccine candidates under development, and in therapeutic vaccines against cancer and autoimmune diseases. It is the carrier protein of CIMAvax-EGF, a therapeutic vaccine used in treatment of patients with lung cancer.[54] Table 2 summarizes patents and publications of this technological package.

\section{VA-MENGOC-BC USE}

\section{IN OTHER COUNTRIES}

In several Latin American countries, strains different from VA-MENGOC-BC circulate, and VA-MENGOC-BC has shown a high percentage of effectiveness against all, in the range of $55 \%-98 \%$ in children aged $\leq 4$ years and $73 \%-100 \%$ in children aged $>4$ years. Table 3 shows results of effectiveness evaluation in several countries, including Cuba.

In 1989-1990, 2.4 million children in the state of Sao Paulo, Brazil were given two doses of VA-MENGOC-BC. Effectiveness was lower than seen in Cuba, probably because isolated interventions were carried out without the rigor or systematic coverage of a campaign or program, in a state with more than 40 million inhabitants. Subsequently, other countries and regions within countries were incorporated, using two-dose vaccination schedules restricted to certain age groups, also with lower coverage than in Cuba, and where there was greater heterogeneity in circulating strains. In general, children from states, provinces or localities with high incidence rates were vaccinated in single interventions not included in a national immunization program, leaving children from neighboring localities and at-risk age groups unvaccinated.
Monoclonal antibodies against $N$. meningitidis were produced and are used for diagnostic purposes, in analytical techniques and in purification processes. Proteomics was used to study the CU-B385/3 strain, which contains in its OMVs all the proteins essential for protection against $N$. meningitidis with immunomodulatory power.[15,52,53]

Ultramicroanalytic ELISA-type assays were carried out-using small amounts of reagents and biological samples-for serologi-
Several reviews including studies of the efficacy of VA-MENGOC$\mathrm{BC}$ against heterologous $N$. meningitidis strains in children aged $\leq 4$ years demonstrate the effectiveness of the vaccine in these conditions.[69-71]

\section{CONCLUSIONS}

Meningococcal disease is no longer a public health problem in Cuba after the introduction of VA-MENGOC-BC vaccine, due to its structure (based on presence, stability and consistency 
of proteoliposomes that confer immunogenicity and protective capacity) and administration strategy. VA-MENGOC-BC is the first vaccine of proven efficacy against $N$. meningitidis serogroup $B$ and is also effective against $C$ and a wide spectrum of heterologous serogroup B strains. It has cross reactivity against $N$. gonorrheae, which broadens the possible prevention spectrum for this infection. The vaccine's systematic application with wide coverage in Cuba's National Immunization Program keeps incidence of meningococcal disease low. Vaccination changes patterns of strains in asymptomatic carriers and circulating strains, which is important for the epidemiology of the disease. Greater survival in children with severe meningococcal disease treated with meningococcal hyperimmune gammaglobulin evidences the protective capacity of vaccineinduced antibodies. VA-MENGOC-BC production technology contributes to the development of the Cuban biotechnology and pharmaceutical industry, obtaining important technological advances, backed by a family of patents and primary publications in the field of vaccines and adjuvants, for current and future benefit. -1 .

\section{REFERENCES}

1. Vieusseux M. Memoire sur la maladie qui a régné à Genève au printemps de 1805. J Med Clin Pharm. 1805;11:163-82. French.

2. Weichselbaum A. Ueber die aetiologie der akuten meningitis cerebro-spinal. Fortschr Med. 1887:5:573-83, 620-63. German.

3. Harrison LH, Trotter CL, Ramsay ME. Global epidemiology of meningococcal disease. Vaccine. 2009 Jun 24;27 Suppl 2:B51-63.

4. Nadel S, Ninis N. Invasive meningococcal disease in the vaccine era. Front Pediatr. $2018 \mathrm{Nov}$ 9;6:321.

5. Lukšič I, Mulić R, Falconer R, Orban M, Sidhu S, Rudan I. Estimating global and regional morbidity from acute bacterial meningitis in children. Croat Med J. 2013 Dec;54(6):510-8.

6. Edmond K, Clark A, Korczak VS, Sanderson C, Griffiths UK, Rudan I. Global and regional risk of disabling sequelae from bacterial meningitis: a systematic review and meta-analysis. Lancet Infect Dis. 2010 May;10(5):317-28.

7. Caugant DA, Maiden MC. Meningococcal carriage and disease-population biology and evolution. Vaccine. 2009 Jun 24;27 Suppl 2:B64-70.

8. Valcárcel M, Rodríguez R, Terry H. La Enfermedad Meningocócica en Cuba: Cronología de una Epidemia. Havana: Editorial de Ciencias Médicas; 1991. Spanish.

9. Zollinger WD, Mandrell RE, Altieri P, Berman S, Lowenthal J, Artenstein MS. Safety and immunogenicity of a Neisseria meningitidis type 2 protein vaccine in animals and humans. J Infect Dis. 1978 Jun;137(6):728-39.

10. Helting TB, Guthöhrlein G, Blackkolb F, Ronneberger $\mathrm{H}$. Serotype determinant protein of Neisseria meningitidis. Large scale preparation by direct detergent treatment of the bacterial cells. Acta Pathol Microbiol Scand C. 1981 Apr;89(2):69-78.

11. Frasch CE, Peppler MS. Protection against group B Neisseria meningitidis disease: preparation of soluble protein and protein-polysaccharide immunogens. Infect Immun. 1982 Jul;37(1):27180.

12. Frøholm LO, Berdal BP, Bøvre K, Gaustad P, Harboe A, Holten E, et al. Meningococcal group $B$ vaccine trial in Norway. Preliminary report of results available November1983. NIPH Ann [Internet]. 1983 Dec [cited 2019 Jan 8];6(2):133-8. Available from: https://www.researchgate.net/ scientific-contributions/61802708

13. Campa C, Sierra VG, Gutiérrez MM, Bisset G, García L, Puentes G, et al. Método para la obtención de una vacuna de amplio espectro protector contra Neisseria meninigitidis del serogrupo B y la vacuna resultante. Patente Cubana CU 21888 A1. Havana: Finlay Institute; 1989. Spanish.

14. Campa C, Sierra VG, Gutiérrez MM, Bisset G, García L, Puentes G, et al. Method for obtaining a vaccine with wide protective range against group B Neisseria meningitidis, the resulting vaccine, gammaglobulin and transfer factor. European Patent EP 0301992; 1995. Available from: https://patentimages.storage.googleapis.com/2a/67/0a/86991ddd224929/ EP0301992A2.pdf

15. Masforrol Y, Gil J, García D, Noda J, Ramos Y, Betancourt $L$, et al. A deeper mining on the protein composition of VA-MENGOCBC@: An OMVbased vaccine against $\mathrm{N}$. meningitidis serogroup $B$ and C. Hum Vaccin Immunother [Internet]. 2017 Nov 2 [cited 2019 Jan 8];13(11):2548-60. Available from: https://www.tandfonline.com/doi/ pdf/10.1080/21645515.2017.1356961

16. Sierra GV, Campa HC, Varcacel NM, García $\mathrm{IL}$, Izquierdo PL, Sotolongo PF, et al. Vaccine against group B Neisseria meningitidis: protection trial and mass vaccination results in Cuba. NIPH Ann. 1991 Dec;14(2):195-207.

17. Tamargo B, Ramírez W, Márquez $\mathrm{Y}$, Cedré B, Fresno M, Sierra G. New proteoliposomic formulation from $\mathrm{N}$. meningitidis serogroup $\mathrm{B}$, without aluminum hydroxide, retains its antimeningococcal protectogenic potencial as well as Th-1 adjuvant capacity. BMC Immunology [Internet]. 2013 Feb 25 [cited 2019 Jan 8];14(Suppl 1):S12. Available from: http://www.biomedcentral.com/1471 $-2172 / 14 / S 1 / S 12$

18. Center for State Control of Medicines, Equipment and Medical Devices (CECMED). VAMENGOCBC $®$. Vacuna antimeningocócica BC. Titular del Registro Sanitario, país: Instituto Finlay de Vacunas. Cuba. Fecha de Inscripción: 22 de octubre de 1987. Havana: Center for State Control of Medicines, Equipment and Medical Devices (CECMED) [Internet]. 1987 [cited 2019 May 2]. 4 p. Available from: http://www.cecmed .cu/sites/default/files/adjuntos/rcp/biologicos/ rcp_va_mengoc_bc_2016_formato_cecmed rev rold 20161025.pdf. Spanish.

19. Tamargo Santos B, Fleitas Pérez C, Infante Bourzac JF, Márquez Nápoles Y, Ramírez González W, Bourg V, et al. Remote induction of cellular immune response in mice by anti-meningococcal nanocochleatesnanoproteoliposomes. Sci Total Environ [Internet]. 2019 Jun 10 [cited 2019 Aug 10];668:1055-63. Available from: https://doi. org/10.1016/j.scitotenv.2019.03.075

20. Tamargo SB, Bungau S, Fleitas Pérez C, Márquez Nápoles Y, Infante Bourzac JF, Oliva Hernández $\mathrm{R}$, et al. Immuno-toxicological Evaluation of the adjuvant formulations for experimental antimeningococcal vaccines without aluminium hydroxide. Rev Chimie (Bucharest). [Internet]. 2019 Apr;70(4):1251-7. Available from: http://www .revistadechimie.ro

21. Pérez Rodríguez A, Dickinson F, Tamargo I, Sosa J, Quintana I, Ortiz P, et al. Resultados y expe- riencias de la vigilancia nacional de meningitis bacteriana en Cuba. Biotecnolo Aplic. 2003;20 (2):118-22. Spanish.

22. Sotolongo Padrón F, Campa Huergo C, Casanueva Gil V, Fajardo Díaz EM, Cuevas Valdespino IE, González Gotera N. Cuban Meningococcal BC vaccine: experiences and contributions from 20 years of application. MEDICC Rev. 2007 Oct;9(1):16-22.

23. Rodríguez $M$, Pérez $A$, Llanes $R$, Dickinson $F$, Cuevas, IE, Pérez K. Características epidemiológicas y microbiológicas en casos confirmados de enfermedad meningocócica en Cuba, 19982007. VacciMonitor. 2013;22(2):1-8. Spanish.

24. Martínez Motas I, Sierra González G, Núñez Gutiérrez N, Izquierdo Pérez L, Climent Ruíz Y, Mirabal Sosa M. Caracterización de cepas de Neisseria meningitidis aisladas de portadores en Cuba durante 20 años. Rev Cubana Med Trop. 2006 May-Aug;58(2):124-33. Spanish.

25. Climent $Y$, Yero D, Martínez I, Martín A, Jolley $\mathrm{KA}$, Sotolongo $\mathrm{F}$, et al. Clonal distribution of disease-associated and healthy carrier isolates of Neisseria meningitidis between 1983 and 2005 in Cuba. J Clin Microbiol. 2010 Mar;48(3):802-10.

26. Law DK, Lorange $M$, Ringuette $L$, Dion $R$, Giguère $M$, Henderson AM, et al. Invasive meningococcal disease in Quebec, Canada, due to an emerging clone of ST-269 serogroup B meningococci with serotype antigen 17 and serosubtype antigen P1.19 (B:17:P1.19). J Clin Microbiol. 2006 Aug;44(8):2743-9.

27. Pérez Rodríguez A, Dickinson Meneses F, Rodríguez Ortega M. Efectividad de la vacuna antimeningocócica VA-MENGOC-BC® en el primer año de vida, Cuba, 1997-2008. Rev Cubana Med Trop. 2011 May-Aug;63(2):155-60. Spanish.

28. Tappero JW, Lagos R, Ballesteros AM, Plikaytis $\mathrm{B}$, Williams D, Dykes J, et al. Immunogenicity of 2 serogroup $B$ outer-membrane protein meningococcal vaccines. A randomized controlled trial in Chile. JAMA. 1999 Apr 28;281(16):1520-7.

29. Perkins BA, Jonsdottir K, Briem H, Griffiths E, Plikaytis $\mathrm{BD}$, Hoiby EA, et al. Immunogenicity of two efficacious outer membrane protein-based serogroup $B$ meningococcal vaccines among young adults in Iceland. J Infect Dis. 1998 Mar;177(3):683-91.

30. Boutriau D, Poolman J, Borrow JR, Findlow J, Diez J, Puig-Barbera J, et al. Immunogenicity and safety of three doses of a bivalent meningococcal outer membrane vesicle vaccine in healthy adolescents. Clin Vaccine Immunol. 2007 Jan;14(1):65-73.

31. Galguera Domínguez M, Sierra González G, Martínez Torres E, Campa Huergo C, Almeida González L, Le Riverend Morales L, et al. Utilización terapéutica de gamma globulina hiperinmune específica en la enfermedad meningocócica del niño. Rev Cubana Pediatr. 1991 Jan-Apr;63(1):55-62. Spanish. 
32. Balboa GJA. Inmunoglobulina humana antimeningococcica: obtención, caracterización y capacidad protectora [thesis]. [Havana]: Finlay Institute; 2006. Spanish.

33. Camero Santiesteban AA, Balboa González JA, Nerey Olivares MC, Malberty Agüero JA, Paradoa Pérez M, Joó Sánchez L, et al. Composición de inmunoglobulinas en la inmunoglobulina humana antimeningocócica. Rev Cubana Farm [Internet]. 1998 Sep-Dec [cited 2019 May 19];32(3):151-6. Available from: http://scielo .sld.cu/scielo.php?script=sci_arttext\&pid=S0034 $-75151998000300001 \&$ Ing $=$ es. Spanish.

34. Wi T, Lahra MM, Ndowa F, Bala M, Dillon JR, Ramón-Pardo P, et al. Antimicrobial resistance in Neisseria gonorrhoeae: global surveillance and a call for international collaborative action. PLoS Med. 2017 Jul 7;14(7):e1002344.

35. Petousis-Harris $H$. Impact of meningococcal group B OMV vaccines, beyond their brief. Hum Vaccin Immunother [Internet]. 2018 May 4 [cited 2019 Jan 8];14(5):1058-63. Available from: https://doi.org/10.1080/21645515.2017.1381810

36. Pérez O, del Campo J, Cuello M, González E, Nuñez N, Cabrera O, et al. Mucosal approaches in Neisseria vaccinology. VacciMonitor. 2009 Jan;18:53-5.

37. Petousis-Harris H, Paynter J, Morgan J, Saxton P, McArdle B, Goodyear-Smith F, et al. Effectiveness of a group $B$ outer membrane vesicle meningococcal vaccine against gonorrhoea in New Zealand: a retrospective case-control study. Lancet. 2017 Sep 30;390(10102):1603-10.

38. Paynter J, Goodyear-Smith F, Morgan J, Saxton P, Black S, Petousis-Harris H. Effectiveness of a Group B outer membrane vesicle meningococcal vaccine in preventing hospitalization from gonorrhea in New Zealand: a retrospective cohort study. Vaccines (Basel). 2019 Jan 5;7(1). pii: E5.

39. Sierra González G, Tamargo Santos B. Adyuvantes inmunológicos para vacunas humanas; estado actual, tendencias mundiales y en Cuba. Rev Anales Acad Cienc Cuba. 2011;1(2):1-32. Spanish.

40. Pérez Martín OG, Bracho Grando GR, Lastre González M, Sierra González VG, Campa Huergo C, Mora González N, et al. Method of obtaining cochlear structures, vaccine compositions, adjuvants and inter mediates thereof. WO 2004/047805 Al [Internet]. Geneva: World Intellectual Property Organization; 2005 Sep 12 [cited 2019 Jan 8]. 3 p. Available from: https://www.re searchgate.net/publication/332263277. Spanish.

41. Lastre González M, Pérez Martín O, Labrada Rosado A, Bidot Martínez I, Pérez Lastre J, Bracho Granada G, et al. Allergy vaccine composition, production method thereof and use of same in allergy treatment [Internet]. Geneva: World Intellectaul Property Organization; 2003 Nov 20 [cited 2019 Jan 8]. Available from: https://patentscope.wipo.int/search/en/detail .jsf?docld=WO2003094964

42. Pérez Martín O, González Aznar E, Romeu Álvarez B, Del Campo Alonso J, Acevedo Grogues R, Lastre González M, et al. Single-time vaccines. WO 2010057447 A1 [Internet]. California: Google Patents; 2010 [cited 2019 Jan 8]. Available from: https://patents.google.com/patent/ WO2010057447A1/. Spanish

43. Pérez Martín O, Pérez Cuello M, Cabrera Blanco O, Balboa González JA, Lastre González M, González Zayas V, et al. Adjuvanted tolerogens as a malaria vaccine. WO2011137876A2 [Internet]. California: Google Patents; 2011 [cited 2019
Jan 8]. Available from: https://patents.google .com/patent/WO2011137876A2/. Spanish.

44. Fernández Molina LE, Sánchez Ramírez B, Suárez Pestana ER, De La Barrera Aira A Mesa Pardillo C, De León Delgado J, et al. Pharmaceutical compositions enhancing the immunogenicity of poorly immunogenic antigens. WO2002045746A2 [Internet]. California: Google Patents; 2011 [cited 2019 Jan 8]. Available from: https://patents.google.com/patent/ WO2002045746A2/. Spanish.

45. Estévez F, Carr A, Solorzano L, Valiente O, Mesa C, Barroso O, et al. Enhancement of the immune response to poorly immunogenic gangliosides after incorporation into very small size proteoliposomes (VSSP). Vaccine. 1999 Aug 20;18(1-2):190-7.

46. Tamargo B, Rosario LA, Batista N, Arencibia DF, Fernández K, Villegas A, et al. Protección inducida por nanococleatos derivados de proteoliposomasde Leptospira interrogans serovar Canicola. VacciMonitor. 2012;21(1):3-9. Spanish.

47. Acevedo R, Callicó A, del Campo J, González E, Cedré B, González L, et al. Intranasal administration of proteoliposome-derived cochleates from Vibrio cholerae 01 induce mucosal and systemic immune responses in mice. Methods 2009 Dec;49(4):309-15

48. Fernández S, Fajardo EM, Mandiarote A, Año G Padrón MA, Acosta M, et al. A proteoliposome formulation derived from Bordetella pertussis induces protection in two murine challenge models. BMC Immunol. 2013;14 Suppl 1:S8

49. Pajón R, Chinea G, Marrero E, González D, Guillén G. Sequence analysis of the structura tbpA gene: protein topology and variable regions within neisserial receptors for transferrin iron acquisition. Microb Pathog [Internet]. 1997 Aug [cited 2018 Oct 15];23(2):71-84. Available from: https://doi.org/10.1006/mpat.1997.0136

50. Delgado M, Yero D, Niebla O, Sardiñas G, González S, Caballero E, et al. Analysis of the genetic variability and immunological properties of the NIpB antigen, a novel protein identified in Neisseria meningitidis. Biotecnol Aplic. 2009 Jan-Mar;26(1):85-7.

51. Menéndez T, Santiago-Vispo NF, Cruz-Leal $Y$, Coizeau E, Garay H, Reyes O, et al. Identification and characterization of phage-displayed peptide mimetics of Neisseria meningitidis serogroup B capsular polysaccharide. Int J Med Microbiol. 2011 Jan;301(1):16-25

52. Uli L, Castellanos Serra L, Betancourt L, Domínguez F, Barberá R, Sotolongo F, et al. Outer membrane vesicles of the VA-MENGOC-BC $\AA$ vaccine against serogroup $\mathrm{B}$ of Neisseria meningitidis: Analysis of protein components by two-dimensional gel electrophoresis and mass spectrometry. Proteomics. 2006 Jun;6(11):3389-99.

53. Gil J, Betancourt LZ, Sardiñas G, Yero D, Niebla $\mathrm{O}$, Delgado $\mathrm{M}$, et al. Proteomic study via a non-gel based approach of meningococcal outer membrane vesicle vaccine obtained from strain CU385: a road map for discovering new antigens. Hum Vaccin. 2009 May;5(5):347-56

54. Center for State Control of Medicines, Equipment and Medical Devices (CECMED). CIMAvax®-EGF. (Conjugado químico de Factor de Crecimiento Epidérmico humano recombinante acoplado a la proteína recombinante rP64K). CIMAvax®-EGF. Vacuna terapéutica indicada para pacientes con cáncer de pulmón de células no pequeñas, en estadios avanzados (IIlb/IV). Titular del Registro Sani- tario: Centro de Inmunología Molecular, Cuba Fecha de Inscripción: 12 de Junio de 2008 [Internet]. Havana: Center for State Control of Medicines, Equipment and Medical Devices (CECMED); 2008 [cited 2018 Oct 15]. Available from: https://www.cecmed.cu/sites/ default/files/adjuntos/rcp/biologicos/rcp_ci ma-vax_egf.pdf. Spanish.

55. Silva R, Selman M, Guillén G, Herrera L, Fernández JR, Novoa LI, et al. Nucleotide sequence coding for an outer membrane protein from Neisseria meningitidis and use of said protein in vaccine preparations. EP $0474313 \mathrm{~A} 2$. [Internet]. Canberra: Lens.org; 1992 Mar 11 [cited 2018 Oct 15]. Available from: https://www.lens.org/lens/ patent/EP 0474313 A2

56. Rodríguez Martínez GM, Viña Rodríguez L, Calvo González L, Cuevas Fiallo A, Chico Véliz E, Crombet Ramos T, et al. Production of an homogeneous vaccine preparation for cancer treatment. WO 2009/003425 Al [Internet]. Canberra: Lens.org; 2012 Mar 21 [cited 2018 Oct 15]. Available from: https://www .lens.org/lens/patent/PT_2184072 E 1

57. Menéndez Medina T, Cruz Leal Y, Coizeau Rodríguez E, Guillén Nieto GE, Santiago Vispo NF, Cinza Estévez Z, et al. Mimotopes of capsular polysaccharides of neisseria meningitidis and pharmaceuti cal formulations. WO 2007/087758 A2 [Internet]. California: Google Patterns; 2007 Nov 15 [cited 2018 Oct 15]. Available from: https:// patents.google.com/patent/WO2007087758A2/

58. Campa Huergo C, Sierra González G, Gutiérrez Vázquez MM, Bisset Jorrín G, García Imia LG, Puentes Rizo GC, et al. Method of producing of an anti-meningococ hyperimmune gamma globulin and gamma globulin produced by method. United States Patent Number: 5,747,653 [Internet]. California: Google Patents; 1998 May 5 [cited 2018 Oct 15]. Available from: https://patents .google.com/patent/US5747653A/en

59. Tania Crombet R, Rodríguez PC, Neninger Vinageras E, García Verdecia B, Lage Dávila A. CIMAvax EGF (EGF-P64K) vaccine for the treatment of non-small-cell lung cancer. Expert Rev Vaccines [Internet]. 2015 [cited 2018 Oct 15];14(10):1303-11. Available from: http://dx.doi .org/10.1586/14760584.2015.1079488

60. Zulueta A, Hermida L, Lazo L, Valdés I, Rodríguez $R$, López $C$, et al. The fusion site of envelope fragments from each serotype of Dengue virus in the P64k protein, influence some parameters of the resulting chimeric constructs. Biochem Biophys Res Commun. 2003 Aug 29;308(3):619-26.

61. Ochoa RF, Sierra G. Vacunas contra la enfermedad meningocócica. In: Ochoa RF, Menéndez J, editors. Prevención de la enfermedad meningocócica.1st ed. Havana: Finlay Ediciones; 2010. p. 67-84. Spanish.

62. Rico O, Almeyda L. Impacto de la vacunación con VA-MENGOC-BC en los niños menores de seis años en algunas provincias de Cuba. Rev Soc Argentina Pediatr Filial Córdoba.1994;3(3):65-8. Spanish.

63. Costa EA, Martins H, Klein CH. Avaliação da proteção conferida pela vacina antimeningocócica BC no Estado de Santa Catarina, Brazil, 1990/92. Rev Saúde Pública. 1996 Apr;30(5):460-70. Portuguese.

64. Noronha CP, Struchiner CJ, Halloran ME. Assessment of the direct effectiveness of $B C$ meningococcal vaccine in Rio de Janeiro, Brazil: a case-control study. Int J Epidemiol. 1995 Oct;24(5):1050-7. 
65. de Moraes JC, Perkins BA, Camargo MCC, Hidalgo NT, Barbosa HA, Sacchi CT, et al. Protective efficacy of a serogroup $B$ meningococcal vaccine in Sao Paulo, Brazil. Lancet. 1992 Oct 31;340(8827):1074-8.

66. Costa EA, Amaral JC, Juárez E. Eficácia da vacina antimeningocócica (VA-MENGOC-BC®) nas condições de uso no Brasil, no período 1989/90. Inf Epidemiol SUS. 1994;3(2):35-9. Portuguese.

67. Galeano LA, Echeverry ML. Efectividad de una vacuna antimeningocóccica en una cohorte de Itaguí, Colombia, 1995. Bol Epidemiol Antioquia. 1995;20(2):110-8. Spanish.

68. Pírez MC, Picón T, Galazka J, Rubio I, Montano A, Ferrari AM. Control de un brote epidémico de enfermedad meningocócica por Neisseria meningitidis serogrupo B. Rev Méd Urug. 2004 Aug;20(2):92-101. Spanish.
69. Ochoa-Azze RF. Cross-protection induced by VA-MENGOC-BC vaccine. Hum Vaccin Immunother [Internet]. 2018 Feb 26 [cited 2019 Jan 8];14(5):1064-8. Available from: https://doi.org/1 $0.1080 / 21645515.2018 .1438028$

70. Ochoa-Azze RF, García-Imía L, Vérez-Bencomo $V$. Effectiveness of a Serogroup B and C Meningococcal vaccine developed in Cuba. MEDICC Rev. 2018 Jul;20(3):22-9.

71. Ochoa-Azze R, García-Imia L. Efectividad de la vacuna VA-MENGOC-BC $®$ contra cepas heterólogas de meningococo B. VacciMonitor. 2016 Aug;25(2):43-8. Spanish.

\section{THE AUTHOR}

V. Gustavo Sierra-González (gsierra6352@ gmail.com), physician specializing in immunol- ogy with a doctorate in medical sciences. Scientific and academic advisor to the president's office, BioCubaFarma, Havana, Cuba.

Submitted: April 16, 2019

Approved for publication: August 31, 2019

Disclosures: The author was one of the main developers of Cuba's VA-MENGOC-BC

vaccine. 